\title{
Involvement of Jasmonic Acid/Ethylene Signaling Pathway in the Systemic Resistance Induced in Cucumber by Trichoderma asperellum T203
}

\author{
Michal Shoresh, Iris Yedidia, and Ilan Chet
}

Department of Biological Chemistry, The Weizmann Institute of Science, Rehovot 76100, Israel. Accepted for publication 16 August 2004.

\begin{abstract}
Shoresh, M., Yedidia, I., and Chet, I. 2005. Involvement of jasmonic acid/ethylene signaling pathway in the systemic resistance induced in cucumber by Trichoderma asperellum T203. Phytopathology 95:76-84.

Trichoderma spp. are effective biocontrol agents for a number of soilborne plant pathogens, and some are also known for their ability to enhance plant growth. It was recently suggested that Trichoderma also affects induced systemic resistance (ISR) mechanism in plants. Analysis of signal molecules involved in defense mechanisms and application of specific inhibitors indicated the involvement of jasmonic acid and

transcription-polymerase chain reaction analysis revealed that $T$. asperellum (T203) modulates the expression of genes involved in the jasmonate/ ethylene signaling pathways of ISR (Loxl, Pall, ETR1, and CTR1) in cucumber plants. We further showed that a subsequent challenge of Trichoderma-preinoculated plants with the leaf pathogen $P$. syringae pv. lachrymans resulted in higher systemic expression of the pathogenesisrelated genes encoding for chitinase 1, $\beta$-1,3-glucanase, and peroxidase relative to noninoculated, challenged plants. This indicates that Trichoderma induced a potentiated state in the plant enabling it to be more resistant to subsequent pathogen infection.
\end{abstract} ethylene in the protective effect conferred by Trichoderma spp. against the leaf pathogen Pseudomonas syringae pv. lachrymans. Moreover, examination of local and systemic gene expression by real-time reverse
Additional keyword: salicylic acid.
Growing awareness of the environmental damage caused by the use of chemical substances for plant disease control in agriculture has raised the need to study biological alternatives, such as activating the defense response of plant crops by inducers that are not toxic to the environment. Trichoderma spp. are effective biocontrol agents for a number of soilborne pathogens and are also known for their ability to enhance plant growth $(32,40)$. However, most studies on reducing disease incidence in soil treated with Trichoderma spp. have focused on microbial interactions rather than host plant responses (12).

Recently, it has been shown that T. asperellum (formerly T. harzianum 203) (19) can penetrate the roots of cucumber seedlings and colonize the epidermis and outer root cortex (38). These interactions also induce host plant resistance to pathogens even in the upper part of the plant (38-40). Trichoderma root inoculation has been shown to be effective against different types of pathogens in a wide variety of plants, including cucumber (9).

Contact with pathogenic and nonpathogenic microorganisms triggers a wide range of defense mechanisms in plants that protect them against invasion. One such response is known as systemic acquired resistance (SAR). SAR, commonly triggered by local infection, can provide long-term resistance throughout the plant to subsequent infection by different pathogens. The SAR response correlates with the activation of pathogenesis-related (PR) genes. This process generally requires the involvement of the signal molecule salicylic acid (SA), which has been shown to increase in both infected and uninfected tissues (34). Colonization of roots by certain rhizospheric bacteria confers another form of dis-

Corresponding author: M. Shoresh; E-mail address: michal.shoresh@weizmann.ac.il

DOI: 10.1094/PHYTO-95-0076

(c) 2005 The American Phytopathological Society ease resistance termed induced systemic resistance (ISR). Several studies have shown that ISR is not an SA-dependent phenomenon but rather requires components of the jasmonic acid (JA) signaling pathway followed by the ethylene signaling pathway $(26,27,36)$.

The first enzyme in the biosynthesis pathway of JA is lipoxygenase (LOX). LOX utilizes linoleic and linolenic acids for the production of JA and controls a feed-forward loop in jasmonate synthesis $(21,28)$.

Several components of the ethylene signal transduction pathway have been identified and include ETR1 and CTR1 $(5,13)$. The ETRl gene is related to the super-family of catalytic receptors in prokaryotes referred to as two-compound regulators (4). The ETR1 protein is an ethylene receptor with histidine protein kinase activity. The CTRl gene acts downstream of the ethylene receptor and encodes a protein most similar to the Raf family of serine/threonine protein kinases that initiate the mitogen-activated protein kinases cascades. Both ETR1 and CTR1 are negative regulators of ethylene signal (14).

The gene encoding for phenylalanine ammonia-lyase (PAL) is believed to be activated by the JA/ethylene signaling pathway in context of induced plant defenses $(7,17,23)$. PAL1 is the first enzyme in the phenylpropanoid biosynthesis pathway, which provides precursors for lignin and phenols, as well as for SA (34). Other enzymes of the phenylpropanoid pathway, including peroxidases, are also induced in resistant reactions $(6,39)$. Peroxidases are also known for their role in the production of phytoalexins, reactive oxygen species, and formation of structural barriers (10).

PR proteins such as $\beta$-1,3-glucanase (PR2) and chitinase (PR3), known to disrupt the fungal mycelial wall, can be induced by SA as well as by pathogenic attack (34). However, studies indicate that some chitinase classes, such as class III chitinases (PR8), are induced by JA and not SA $(30,31)$. 
In order to study the mechanisms by which $T$. asperellum induces plant resistance to pathogen infection, we examined the involvement of the plant signal molecules (JA, ethylene, and SA) by measuring hormone levels and the effect of specific inhibitors. We also analyzed the local and systemic expression of defenserelated genes in cucumber seedlings inoculated with T. asperellum T203 and challenged with the leaf pathogen Pseudomonas syringae pv. lachrymans. Our study indicates that unlike pathogen-induced SAR, the JA/ethylene signaling pathway is involved in the Trichoderma-mediated plant protection process.

\section{MATERIALS AND METHODS}

Plant material. Seeds of cucumber (Cucumis sativus L. cv. Delila) from Gedera Seeds Co. (Gedera, Israel) were used in this experiment. Plant growth medium (PGM) was prepared according to Yedidia et al. (38).

Fungal material. T. asperellum (T. harzianum strain T203) was grown on potato dextrose agar (PDA) (Difco Laboratories, Sparks, MD). Synthetic medium (SM) for T. asperellum was prepared according to Yedidia et al. (38). The inoculum consisted of $1 \mathrm{ml}\left(10^{9}\right.$ spores, counted by hemacytometer) of 10-dayold $T$. asperellum cultured on PDA added to a 250-ml flask containing $100 \mathrm{ml}$ of SM. The flask was shaken at $150 \mathrm{rpm}$ for 16 to $18 \mathrm{~h}$ at $30^{\circ} \mathrm{C}$ to allow spore germination. The inoculum was then separated from the growth medium by centrifugation at $5,000 \mathrm{rpm}$ at $4{ }^{\circ} \mathrm{C}$ followed by two washes with $100 \mathrm{ml}$ of distilled water.

Axenic growth system. Seeds were surface-sterilized in $2.0 \%$ $\mathrm{NaOCl}$ for $2 \mathrm{~min}$ and thoroughly washed with sterile distilled water. Seeds (25 per box) were placed on a sterile gauze sheet, which was then placed in an axenic hydroponics growth system (38). Plants were grown in a controlled environment: $26^{\circ} \mathrm{C}, 80 \%$ relative humidity, light $300 \mu \mathrm{E} / \mathrm{m}^{2} \mathrm{~s}$, and a circadian cycle of $14 \mathrm{~h}$ light and $10 \mathrm{~h}$ darkness. The growth chambers enabled the development of cucumber seedlings for up to 3 weeks.

Trichoderma plant inoculation. Mycelial inoculum was added under aseptic conditions to the PGM of 7-day-old seedlings to a final concentration of $\pm 10^{5}$ germinated spores per $\mathrm{ml}$ (38). Control plants were treated with sterile distilled water.

Plants were harvested 1, 3, 6, 9, 24, 48, and $72 \mathrm{~h}$ postinoculation (hpi). The induced expression of defense-related genes was examined in roots and leaves. These experiments were repeated twice and each time point represents approximately 20 plants per experiment.

Bacterial inoculum. $P$. syringae pv. lachrymans was grown in tryptic soy broth overnight at $30^{\circ} \mathrm{C}$. Bacterial cells were pelleted at 5,000 rpm and resuspended in sterile saline-phosphate buffer ( $5 \mathrm{mM}, \mathrm{pH} 7.2)$. Challenge was performed $48 \mathrm{~h}$ after inoculating Trichoderma to the PGM. P. syringae pv. lachrymans bacterial suspension $(20 \mu \mathrm{l}$; OD $=0.5)$ containing $0.01 \%$ (vol/vol) surfactant (Tween 20) was applied to the surface of the cotyledons and gently smeared with a sterile tip. Bacterial inoculation was performed under aseptic conditions. Multiplication of $P$. syringae pv. lachrymans in the cotyledon was assessed $48 \mathrm{~h}$ after bacterial inoculation. For each treatment, 10 randomly selected leaves were rinsed thoroughly in sterile water and homogenized in a sterile solution of $10 \mathrm{mM}$ phosphate-saline buffer. Dilutions were plated onto Pseudomonas-selective King's B agar supplemented with a $1 \mathrm{ml} /$ liter solution containing basic fuchsin at $9 \mathrm{mg} / \mathrm{ml}$, cycloheximide at $200 \mathrm{mg} / \mathrm{ml}$, nitrofurantoin at $10 \mathrm{mg} / \mathrm{ml}$, and nalidixic acid at $23 \mathrm{mg} / \mathrm{ml}$. After incubation at $28^{\circ} \mathrm{C}$ for 2 days, the number of $P$. syringae pv. lachrymans colony forming units per gram of infected tissue was determined.

For controls, we used noninoculated, nonchallenged plants $(-\mathrm{T}-\mathrm{P})$; noninoculated, challenged plants $(-\mathrm{T}+\mathrm{P})$; and inoculated, nonchallenged plants $(+\mathrm{T}-\mathrm{P})$. Plant roots and leaves were sampled $48 \mathrm{~h}$ post- $P$. syringae pv. lachrymans infection to exam- ine expression levels of the studied genes. These experiments were repeated three times with approximately 15 plants per treatment in each experiment.

For measurement of the number of necrotic lesions, $P$. syringae pv. lachrymans bacterial suspension (optical density at $600 \mathrm{~nm}$ $\left[\mathrm{OD}_{600}\right]=0.1$ ) was applied to the surface of the first and second leaves of cucumber seedlings. Six droplets of $10 \mu \mathrm{l}$ were applied on each leaf. Necrotic lesions were examined after 5 days.

Treatment with plant hormone inhibitors. Diethyldithiocarbamic acid (DIECA; Sigma, St. Louis), a potent inhibitor of jasmonate biosynthesis (22), was added to the root compartment at final concentrations of 50 and $100 \mu \mathrm{M}, 1 \mathrm{~h}$ after Trichoderma inoculation.

Silver thiosulfate (STS), an inhibitor of ethylene action (1), was prepared by mixing solutions of $0.1 \mathrm{M}$ sodium thiosulfate with $0.1 \mathrm{M}$ of silver nitrate in a 4:1 ratio. STS was added to the root compartment at final concentrations of 0.25 and $0.5 \mathrm{mM}, 3 \mathrm{~h}$ after Trichoderma inoculation.

Root colonization efficiency. Trichoderma ability to colonize roots with or without STS or DIECA was tested in cucumber roots 2 days after Trichoderma inoculation and treatment with the inhibitors. Five plants per replicate were harvested, and their root systems washed, weighed, and homogenized using Ultra-Turrax apparatus (Janke \& Kunkel, Staufen, Germany) with water for 1 min. Serial dilutions from both treated and untreated plants were assayed for colony forming units on Trichoderma-selective plates. Each treatment was repeated six times. Data were subjected to one-way ANOVA at $P=0.05$.

Trichoderma-selective plates contained $\mathrm{MgSO}_{4} \cdot 7 \mathrm{H}_{2} \mathrm{O}$ $(0.2 \mathrm{~g} /$ liter $) ; \mathrm{K}_{2} \mathrm{HPO}_{4}(0.9 \mathrm{~g} /$ liter $) ; \mathrm{KCl}(0.15 \mathrm{~g} /$ liter $) ; \mathrm{NH}_{4} \mathrm{NO}_{3}$ (1 g/liter); glucose (3 g/liter); chloramphenicol (0.25 g/liter); p-dimethylaminobenzenediazo sodium sulfonate (Dexon $70 \%$ wettable powder [w.p.], Farbenfabrik Bayer AG, Germany) (0.3 g/liter); pentachloronitrobenzene (Terraclor $75 \%$ w.p., Olin Chemicals, Charlestown, TN) (0.2 g/liter); Rose-bengal (0.15 g/liter); and Bacto agar (Difco Laboratories) (20 g/liter).

Ethylene measurement. Two-week-old plants with or without prior Trichoderma inoculation were weighed and placed in 30-ml gas-tight tubes. After $1 \mathrm{~h}, 1-\mathrm{ml}$ gas samples were withdrawn through the rubber seal. The concentration of ethylene was detected by gas chromatography as described by Thompson et al. (35). Wounding of leaves was done to verify our ability to detect ethylene production in plants (data not shown).

SA measurement. Total SA was extracted from cucumber roots and leaves and quantified by high-performance liquid chromatography analysis with spectofluorescence monitoring as described by Enyedi et al. (8). Treatment with isonicotinic acid, a functional SA analog, was performed to verify our ability to detect SA production in plants (data not shown).

RNA isolation. For RNA analysis, roots, cotyledons, and leaves were harvested at a set of time points after the inoculation and stored at $-70^{\circ} \mathrm{C}$ until required. Total RNA was extracted using the EZ-RNA Total RNA Isolation Kit (Biological Industries Co., BeitHaemek, Israel). RNA was treated with RNase-free DNase I in 40 $\mathrm{mM}$ Tris- $\mathrm{HCl}$ (pH 7.9), $10 \mathrm{mM} \mathrm{NaCl}, 6 \mathrm{mM} \mathrm{MgCl}_{2}$, and $10 \mathrm{mM}$ $\mathrm{CaCl}_{2}$ for $30 \mathrm{~min}$ at $37^{\circ} \mathrm{C}$ (Roche, Mannheim, Germany). This was followed by a phenol/chloroform and chloroform extraction and a subsequent ethanolic precipitation.

Reverse transcription. After treatment with DNase, $1 \mu \mathrm{g}$ of total RNA was used for a reverse transcription (RT) reaction using Expand Reverse Transcriptase (Roche) according to the manufacturer's instructions.

Cloning and sequencing. Degenerate primers designed according to several known Pall and CTRl plant genes were used to isolate these genes with the Expand High Fidelity PCR System (Roche). Primer sequences are as follows: Pall, forward 5'TGGAACA(T/C)(A/C)TTTTGGATGGAA-3' and reverse $5^{\prime}$ GCTGTTTT(T/C)CTTG(C/A)TGAGATTA-3'; and CTR1, for- 
ward $5^{\prime}-(\mathrm{C} / \mathrm{T}) \mathrm{ACCGTG}(\mathrm{G} / \mathrm{C}) \mathrm{TGA}(\mathrm{T} / \mathrm{G}) \mathrm{TGG}(\mathrm{C} / \mathrm{A}) \mathrm{ATGG}-3^{\prime}$ and reverse 5'-CCCACAA(A/G)ATGAC(A/C)CC(A/G)AAG-3'. Polymerase chain reaction (PCR) fragments were cloned in pGEM-T Easy Vector (Promega, Madison, WI) and both strands were sequenced. Sequences are deposited as GenBank accession nos. AF529240 and AF529239 for Pall and CTR1, respectively.

Quantitative PCR. According to these sequences and known sequences of other $C$. sativus genes, primers were designed for the quantitative PCR experiments. The size of amplified fragment for all genes was $200 \mathrm{bp}$, and the annealing temperature of all primers was $60^{\circ} \mathrm{C}$. The sequences of the primers used were as follows: Chit1, forward 5'-TGGTCACTGCAACCCTGACA-3' and reverse 5'-AGTGGCCTGGAATCCGACT-3' (gi|167514); ETR1, forward 5'-GCCATTGTTGCAAAAGCAGA-3' and reverse 5'-GCCAAAGACCACTGCCACA-3' (gi|3641253); $\beta$-1,3glucanase gene, forward 5'-TCAATTATCAAAACTTGTTCGATGC- $3^{\prime}$ and reverse $5^{\prime}$-AACCGGTCTCGGATACAACAAC- ${ }^{\prime}$ (gi|3273193); Lox1, forward 5'-AAGGTTTGCCTGTCCCAA-

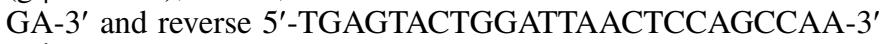
(gi|3668062); Pal1, forward 5'-ATGGAGGCAACTTCCAAGGA$3^{\prime}$ and reverse $5^{\prime}$-CCATGGCAATCTCAGCACCT-3'; peroxidase gene, forward $5^{\prime}$-AGAGCAACAAGGTCGGTTTCA-3' and reverse 5'-GTGCCGACATCCTAGCTCAAG-3' (gi|553047); CTR1, forward 5'-AAACACGTCGGATAAATATGGCTT-3' and reverse 5'-CATCCATTCAGGCGTTCCAG-3'; and 18s, forward 5'-GTTGCTTTAAGGACTCCGCCA-3' and reverse 5'-AGGGGTACCTCCGCATAGCTAG-3' (gi|7595414). PCR reactions were carried out in 96-well plates ( $25 \mu \mathrm{l}$ per well) in a reaction buffer containing 1× SYBR Green PCR Master Mix (PE Applied Biosystems, Foster, CA), $120 \mathrm{nM}$ primers (for each forward and reverse primers), and 1/20 of the RT reaction. Quantitative analysis was performed using the GeneAmp 5700 Sequence Detection System (PE Applied Biosystems) with PCR conditions of $95^{\circ} \mathrm{C}$ for $15 \mathrm{~s}$ and $60^{\circ} \mathrm{C}$ for $1 \mathrm{~min}$ for 40 cycles. The absence of primer-dimer formation was checked in no-template controls. Specificity of primers to cucumber genes was examined by using Trichoderma DNA and reverse-transcribed RNA as templates. The 18s ribosomal cDNA was used as a control reference. Each sample was examined in duplicate. We first normalized the expression of the specific gene versus the control reference with the formula $2^{-\Delta \Delta C_{T}}$, where $\Delta C_{T}=C_{T}$ specific gene $-C_{T}$ reference gene, and $\Delta \Delta C_{T}=$ $\Delta C_{T}$ - arbitrary constant (the highest $\Delta C_{T}$ ). More details can be found in the PE Applied Biosystems Sequence Detector User Bulletin 2. The $C_{T}$ (threshold cycle) value is defined as the PCR cycle number that crosses an arbitrarily placed threshold line.

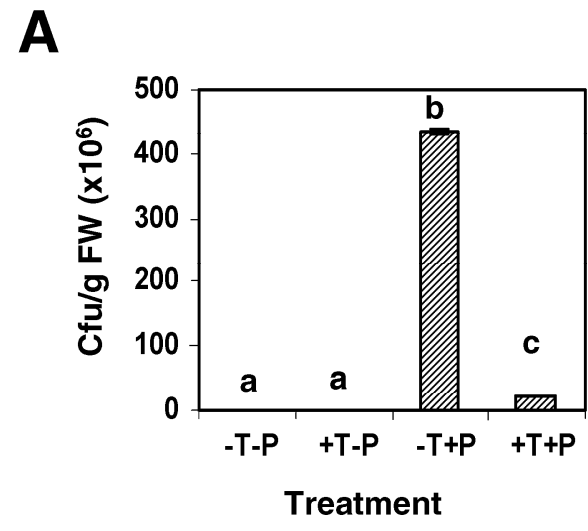

\section{RESULTS}

Involvement of plant signal molecules in the defense responses induced by Trichoderma inoculation. An aseptic hydroponics growth system (38) was used to control growth conditions and medium composition and to eliminate unwanted microorganisms as well as to enable spatial separation of the inducing agent from the pathogen.

First, we tested the protective effect of Trichoderma-induced resistance on pathogen challenge. We assessed $P$. syringae pv. lachrymans proliferation in infected cucumber cotyledons with or without Trichoderma preinoculation. Leaves and roots of the same plants were also used for the gene expression study. Multiplication of $P$. syringae pv. lachrymans was significantly lower in the $+\mathrm{T}+\mathrm{P}$ plants compared with that of the $-\mathrm{T}+\mathrm{P}$ plants, indicating that inhibition of bacterial multiplication had occurred (Fig. 1A). In addition, we infected leaves and the proportion of necrotic lesions per leaf was assessed. A 50\% reduction in the proportion of necrotic lesions was observed in the $+\mathrm{T}+\mathrm{P}$ plants compared with the $-\mathrm{T}+\mathrm{P}$ plants (Fig. 1B), 5 days postchallenge.

Ethylene production was measured in plants at several time points post-Trichoderma inoculation. No significant difference was observed between Trichoderma-inoculated and noninoculated plants (Fig. 2). Similar results were obtained with detached roots (data not shown). Nevertheless, when plants were treated with STS (an inhibitor of ethylene action), the ability of Trichoderma

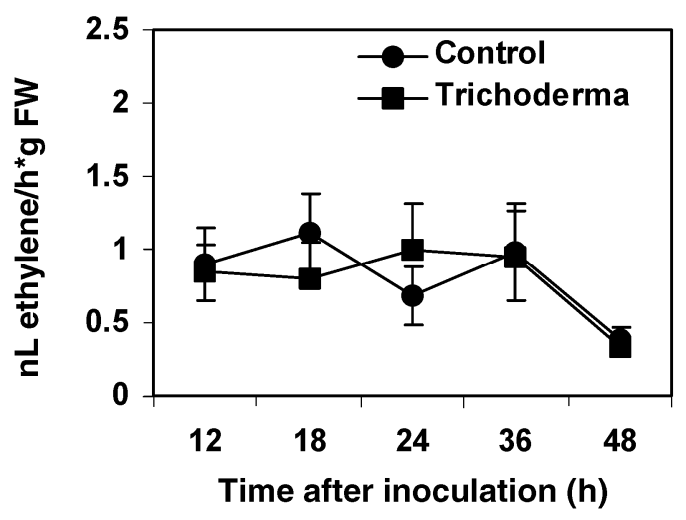

Fig. 2. Time course of ethylene production by plants with or without Trichoderma inoculation to the root compartment. The presented values are means $( \pm \mathrm{SE})$ for seven repeats.

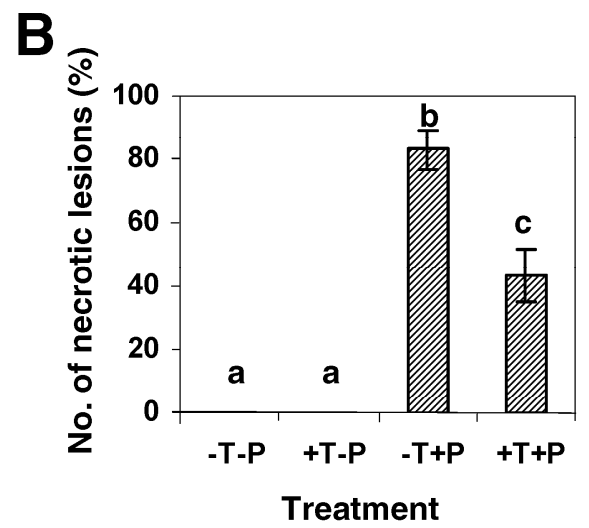

Fig. 1. A, Quantification of Trichoderma protective effect against multiplication of Pseudomonas syringae pv. lachrymans (in challenged cotyledons, $96 \mathrm{~h}$ after infection. Control plants (+T-P and -T-P) were treated with distilled water. Bars are means \pm 1 standard deviation of three independent experiments from which 10 cotyledons were randomly selected. Different letters indicate statistically significant differences between treatments by one-way analysis of variance (ANOVA) and multiple range test for comparing means $(\alpha=0.05, n=10)$. B, Disease severity is expressed as proportion of necrotic lesions, viewed after 5 days, relative to the number of droplets applied to each leaf. Different letters indicate statistically significant differences between treatments by one-way ANOVA and multiple range test for comparing means $(\alpha=0.05, n=15)$. 
to protect plants against challenge infection with $P$. syringae pv. lachrymans was significantly reduced (Fig. 3A). Similarly, treating plants with DIECA (inhibitor of JA biosynthesis) could abolish the protective effect of Trichoderma on plants against challenge infection with $P$. syringae pv. lachrymans in a quantitative dependent manner (Fig. 3B). Both root treatments with STS or DIECA did not inhibit root inoculation by Trichoderma (data not shown), nor did they affect the ability of $P$. syringae pv. lachrymans to multiply in the leaves of control plants (Fig. 3).

We also examined the levels of total SA produced by treated plants. No difference in both roots and leaves of Trichodermainoculated and noninoculated plants was observed (Fig. 4). Further, challenging the plants with the pathogen P. syringae pv. lachrymans did not produce any differences in SA levels between roots of Trichoderma-preinoculated and noninoculated plants. In the leaves, an elevation of SA level was observed in $P$. syringae pv. lachrymans-infected plants $96 \mathrm{~h}$ post- $P$. syringae pv. lachrymans infection but not in the Trichoderma-preinoculated plants.

Expression of signal molecules-related genes post-Trichoderma root inoculation. CTRl, an ethylene signal-associated gene, and Pall, a gene coding for an enzyme activated by the JA/ ethylene signaling pathway and involved in the production of antimicrobial compounds, were cloned from $C$. sativus by PCR. Our partial protein sequences were found to strongly resemble the homologous proteins from Arabidopsis spp. (88 and 93\% identity, respectively, and 94 and $96 \%$ similarity, respectively, Fig. 5A and $\mathrm{B})$.

In addition to these genes, we also analyzed the expression of two other known cucumber genes: Loxl, involved in JA synthesis, and ETR1, coding for the ethylene receptor.

To assess the expression of these genes in response to root inoculation with Trichoderma spp., 1-week-old cucumber seedlings were inoculated with Trichoderma and harvested 1, 3, 6, 9, 24, 48, and 72 hpi. Expression levels of these genes were analyzed both locally (roots) and systemically (leaves).

Lox 1 mRNA expression level was already induced in the roots 1 hpi with Trichoderma spp. and a second increase was observed within 9 h. Maximal levels of Loxl mRNA were obtained at $24 \mathrm{hpi}$. The first peak was fourfold and the second peak was twoto threefold larger than the control (Fig. 6A). Loxl was hardly expressed in leaves (data not shown), regardless of whether the plants had been inoculated with Trichoderma spp. or not. Other studies also demonstrate that Loxl is hardly expressed in seedling leaves (37).

Expression levels of Pall increased in roots as early as $1 \mathrm{hpi}$ with Trichoderma spp. Pall expression peaked again at $24 \mathrm{hpi}$. In leaves, however, Pall expression levels began to increase between 9 and 24 hpi, reaching a maximum at 48 hpi (Fig. 6B).

Expression levels of ETRI and CTRI were studied in order to determine the involvement of ethylene signaling in plant response to Trichoderma inoculation. Expression levels of both ETRI and CTRl were elevated in roots starting from 9 hpi and peaking at 24 hpi. In leaves, a similar time course of expression was observed for ETRI. In contrast, CTRl expression level increased in noninoculated plants approximately three times more than in Trichoderma-inoculated plants (Fig. 7A and B). Since ETRI and $C T R 1$ are negative regulators of ethylene response, down-regulation of these genes is an indication of ethylene involvement in the defense response.

In general, we demonstrated that Trichoderma interaction with plants affected expression levels of plant genes related to the JA/ ethylene signaling pathway.

Effects of $P$. syringae pv. lachrymans infection on Trichoderma-induced gene expression. One-week-old cucumber seedlings were inoculated with Trichoderma spp. and $48 \mathrm{~h}$ later the cotyledons were challenged with the leaf pathogen $P$. syringae $\mathrm{pv}$. lachrymans ( $+\mathrm{T}+\mathrm{P}$ plants). Expression of defense-related genes was examined in leaves and roots of these plants $(+\mathrm{T}+\mathrm{P})$ and control plants, i.e., nontreated plants (-T-P), Trichoderma-inoculated and $P$. syringae pv. lachrymans-noninfected plants $(+\mathrm{T}-\mathrm{P})$, or Trichoderma-noninoculated and $P$. syringae pv. lachrymansinfected $(-\mathrm{T}+\mathrm{P})$ plants.

There was no significant difference between the ETR 1 expression levels in roots and leaves of plants treated either with Trichoderma spp., P. syringae pv. lachrymans, or Trichoderma spp. and $P$. syringae pv. lachrymans. However, in both tissue types, ETRl expression level tended to be lower in plants preinoculated with Trichoderma spp. and challenged with $P$. syringae pv. lachrymans $(+\mathrm{T}+\mathrm{P})$ than in $P$. syringae $\mathrm{pv}$. lachrymans-challenged plants $(-\mathrm{T}+\mathrm{P}$; Fig. $8 \mathrm{~A})$.

Whereas ETRI revealed only minor reduction of expression, CTRI expression in roots of plants inoculated with Trichoderma spp. and challenged with $P$. syringae pv. lachrymans $(+\mathrm{T}+\mathrm{P})$ was significantly lower than in plants treated only with either Trichoderma spp. $(+\mathrm{T}-\mathrm{P})$ or $P$. syringae pv. lachrymans $(-\mathrm{T}+\mathrm{P})$. In leaves, however, we observed no significant difference between plants challenged with $P$. syringae pv. lachrymans with or without prior Trichoderma inoculation (Fig. 8B).

Three genes encoding for proteins with known antipathogenic activity (chitinase 1, $\beta$-1,3-glucanase, and peroxidase) were examined in order to monitor the defense status of the plant.
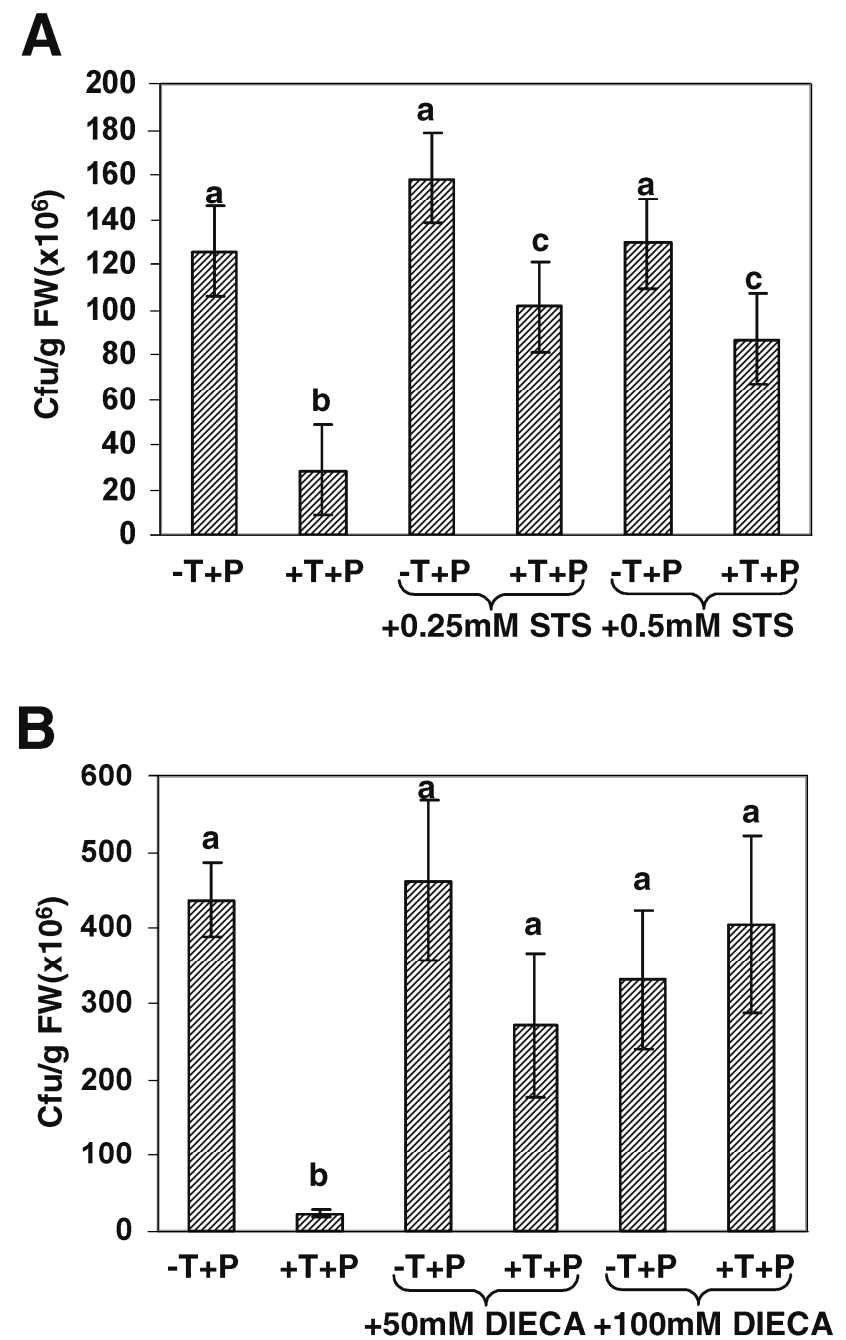

Fig. 3. Effect of A, silver thiosulfate (STS) and B, diethyldithiocarbamic acid (DIECA) treatments on the protective effect of Trichoderma inoculation against Pseudomonas syringae pv. lachrymans multiplication in cotyledons. The presented values are means $( \pm \mathrm{SE}, n=5)$. Different letters indicate statistically significant differences between treatments (one-way analysis of variance and multiple range test for comparing means, $\alpha=0.05)$. The experiments were repeated with similar results. 


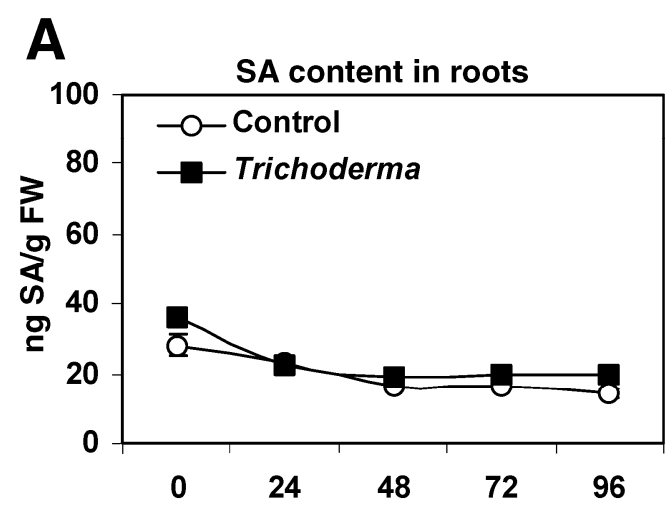

Time after Trichoderma inoculation (h)

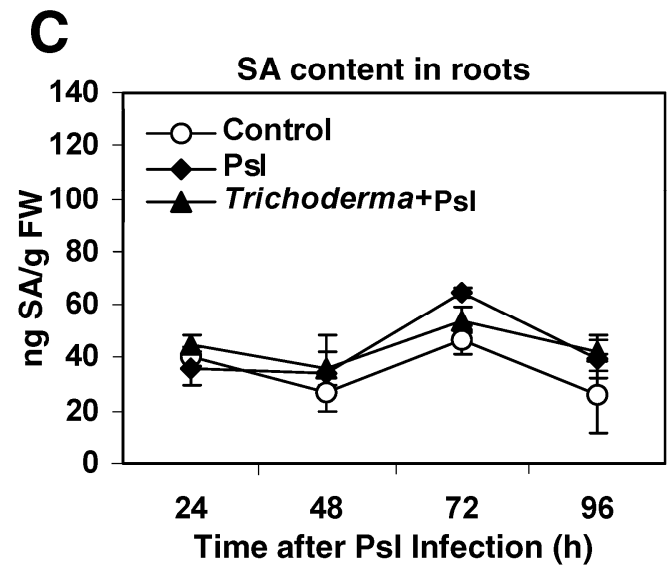

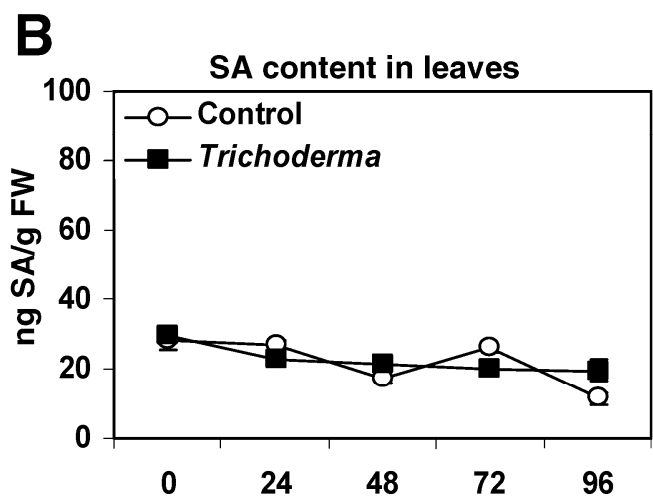

Time after Trichoderma inoculation (h)

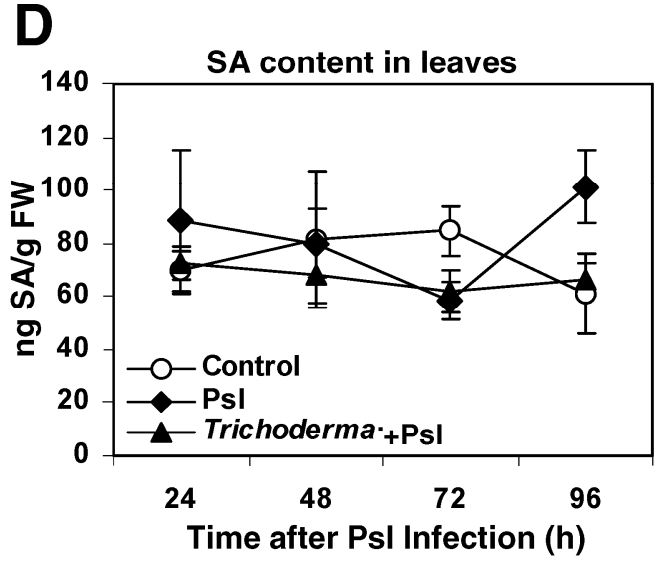

Fig. 4. Time course of the total salicylic acid (SA) content in roots and leaves of plants with or without Trichoderma root inoculation (A and B), and after Pseudomonas syringae pv. lachrymans (Psl) infection, with or without prior Trichoderma inoculation $(\mathbf{C}$ and $\mathbf{D})$. The presented values are means $( \pm \mathrm{SE}, n=5)$.

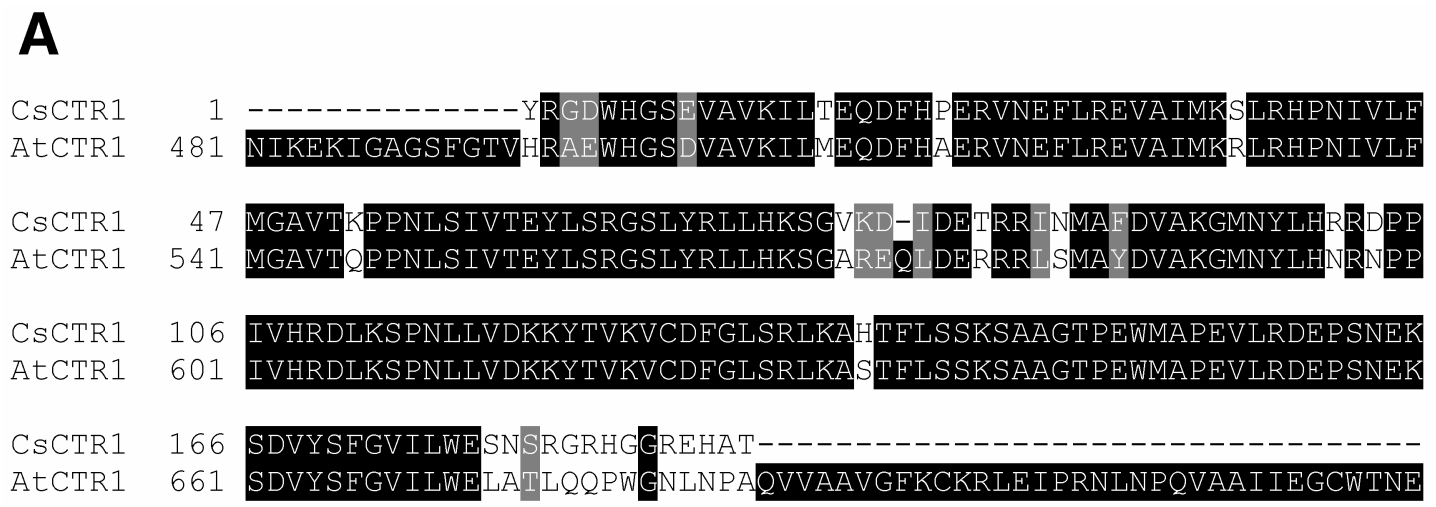

B

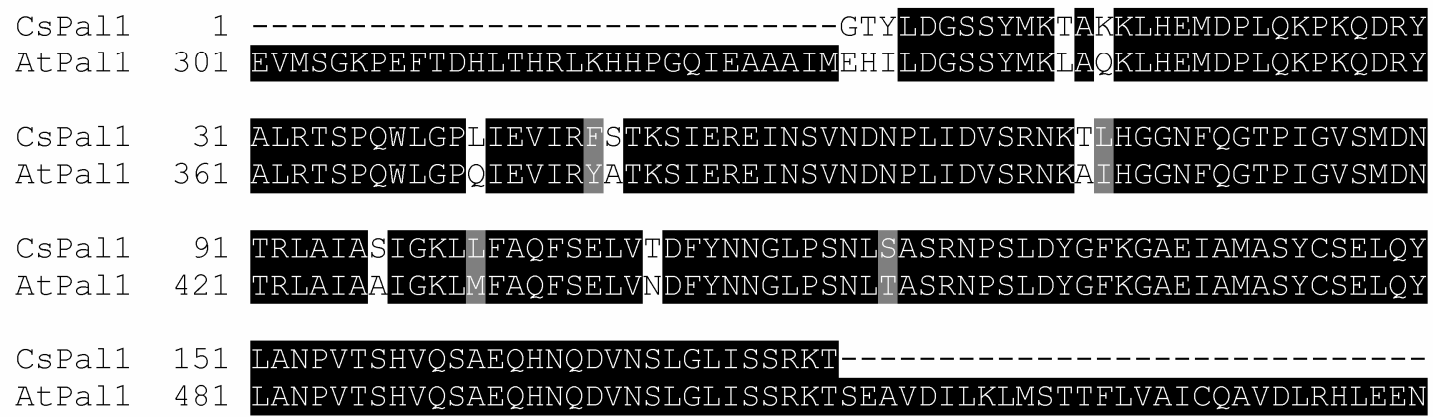

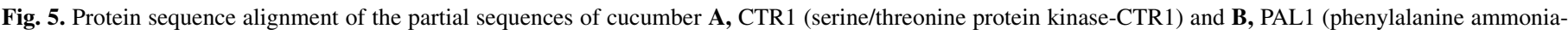
lyase) with their homologues from Arabidopsis thaliana. 
These genes were upregulated locally within $24 \mathrm{~h}$ post-Trichoderma inoculation (data not shown). In leaves, however, elevation of expression levels of these genes appeared within $48 \mathrm{~h}$ postTrichoderma inoculation and was small and temporary (Chitl, peroxidase gene) or hardly expressed at all ( $\beta$-1,3-glucanase gene; data not shown).

In leaves of plants inoculated with Trichoderma spp. and infected with $P$. syringae pv. lachrymans, Chitl expression levels were twofold higher than in plants infected only with $P$. syringae pv. lachrymans, whereas leaves of plants inoculated only with Trichoderma spp. did not express Chitl at this time point at all (Fig. 9A). Leaves of plants inoculated with Trichoderma spp. and infected with $P$. syringae pv. lachrymans also manifested a significant elevation in $\beta$-1,3-glucanase gene mRNA levels compared with plants infected only with $P$. syringae pv. lachrymans (Fig. 9B). Plants inoculated with Trichoderma spp. and challenged with $P$. syringae pv. lachrymans expressed elevated levels of expression of peroxidase gene in leaves relative to plants treated only with Trichoderma spp. or P. syringae pv. lachrymans (Fig. 9C).

\section{DISCUSSION}

While most studies focus on direct antagonistic mechanisms between Trichoderma spp. and plant pathogens, we examined the ability of Trichoderma spp. to induce defense response in the plant. The protective effect of Trichoderma-mediated plant resistance to pathogen challenge was demonstrated by both the reduction of bacterial multiplication in the leaves and the number of necrotic lesions per leaf in the Trichoderma-preinoculated plants $(+\mathrm{T}+\mathrm{P})$ relative to noninoculated controls $(-\mathrm{T}+\mathrm{P}$, Fig. $1 \mathrm{~A}$ and $\mathrm{B})$. Application of autoclaved T. asperellum mycelial inoculum to the roots did not appear to have any effect on disease reduction (data not shown), indicating that only live Trichoderma interacting with plant roots could exert this effect.

It is important to note that Trichoderma was not detected on shoots of inoculated plants. Moreover, Trichoderma could not antagonize $P$. syringae pv. lachrymans growth in dual cultures (data not shown). These observations indicate that the protective effect conferred by Trichoderma to the plant against the pathogen infection was not due to direct antagonism but rather a plantmediated phenomenon.

The present study was aimed at identifying plant signals involved in the induction of systemic defense responses by T. asperellum.

Three major signal molecules are known to be involved in systemic defense responses of plants: SA, commonly shown to be involved in SAR, and JA and ethylene, which were shown to be involved in ISR $(1,27,34)$. Our results demonstrated that no significant difference occurred in ethylene levels in any of the treatments (Fig. 2). However, treatment with an inhibitor of ethylene action (STS) strongly inhibited the protective effect of Trichoderma on plants (Fig. 3A), thus indicating that ethylene signal is required for this effect. Moreover, application of JAproduction inhibitor (DIECA) completely abolished the protective effect of Trichoderma on plants (Fig. 3B). These results strongly suggest the involvement of JA/ethylene signal transduction pathway in the plant-induced resistance mediated by Trichoderma. This coincides with other studies, which have shown that JA and ethylene are the signal molecules involved in ISR mediated by biocontrol rhizobacteria (reviewed in literature citation 27). Such studies also demonstrated that rhizobacteria-mediated ISR is not accompanied by a detectable increase in JA or ethylene levels although it requires sensitivity to these hormones $(18,26)$.

On the other hand, SA content did not differ between Trichoderma-inoculated and noninoculated plants even post- $P$. syringae pv. lachrymans challenge infection (Fig. 4). The levels of SA rose only in leaves of $P$. syringae pv. lachrymans-infected plants with- out Trichoderma pretreatment $(-\mathrm{T}+\mathrm{P})$, indicating the development of SAR in these plants.

To further investigate the involvement of these hormones in plant reaction to Trichoderma inoculation, we have studied the expression pattern of several defense-related genes. Several genes were shown to be involved in signal transduction, one such gene is Lox. LOX catalyzes the addition of molecular oxygen at either the C9 or C13 residue of linoleic and linolenic acids. The 13hydroperoxylinolenic acid, formed by 13 -LOX, is the substrate for allene oxide synthase, giving rise after reduction and a series of $\beta$-oxidations to JA.

The amino acid sequence of LOX1 was found to be identical to that of the cucumber lipid body lox (X92890), except for one conserved amino acid substitution outside the active site. The lipid body lox has been reported to have 13-LOX activity (11), indicating that cucumber LOX1 has the same activity leading eventually to the formation of JA.
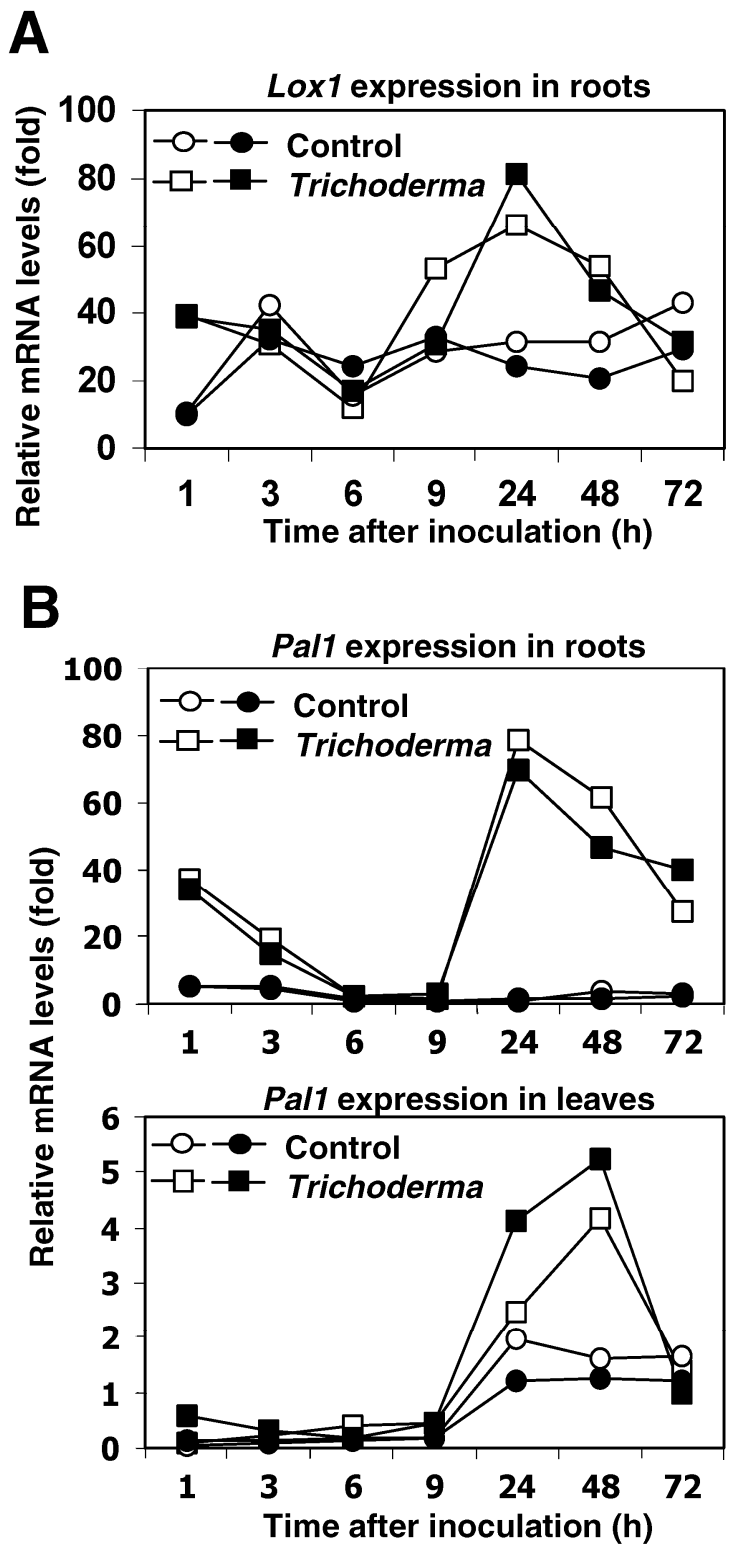

Fig. 6. Time course of the induction of A, Loxl and B, Pall gene expression. Expression was measured in roots and leaves of cucumber plants after Trichoderma inoculation to the root compartment (time zero). Two experiments were conducted, each including approximately 20 plants. Open symbols signify experiment 1 ; closed symbols signify experiment 2 . The internal standard deviation values for each experiment were smaller than the size of the symbols. - and $\square$ indicate inoculation with Trichoderma; $\bullet$ and $\bigcirc$ indicate controls. 
We observed two peaks of Loxl expression in the roots (Fig. 6A) in response to Trichoderma inoculation. The first peak was observed as early as $1 \mathrm{hpi}$, while the second peak appeared at 24 hpi. Using Trichoderma cellulase, Martinez et al. (20) demonstrated that LOX activity peaked a few hours after infiltration of melon cotyledons followed by a JA peak at $12 \mathrm{~h}$. Other studies have shown that methyl jasmonate (MeJA) can induce several of the enzymes in the LOX pathway, as well as their corresponding genes $(2,3)$. Correspondingly, our results indicated local induction of Loxl by Trichoderma followed by a second peak possibly resulting from the initiation of the octadecanoic pathway and the synthesis of JA. Another indication for the activation of octadecanoic pathway comes from the analysis of hydroperoxide lyase gene, which is also upregulated by the interaction of Trichoderma with plant roots (41). Taken together, our results indicate that Trichoderma activates the octadecanoic pathway in plant roots with Loxl being activated immediately. This activation apparently leads to the production of JA signal.

Ethylene response is considered to act downstream to JA response in nonpathogenic rhizobacteria-mediated ISR. In order to better understand the ethylene response during Trichodermamediated ISR, expression of two genes from the ethylene signaling pathway, ETR1 and CTR1, was analyzed. ETR1 and CTR1 gene products work together to negatively regulate ethylene response pathway in the absence of ethylene $(13,14,29)$. Ethylene binding to the receptor would down-regulate the activity of the ETR1/CTR1 complex and result in de-repression of the response pathway.

In roots, both ETRI and CTRI expression peaked at 24 hpi (Fig. 7A and B), suggesting that ethylene response in the roots is inhibited. Such phenomenon was well documented in symbiotic systems where the plant-fungus interaction results in local silencing of the plant defense response to enable symbiotic interaction to develop.

In the leaves, an increased expression of ETRl was recorded in response to Trichoderma inoculation. However, this increase was followed by reduction to below control level (Fig. 7A at $72 \mathrm{hpi}$ ).

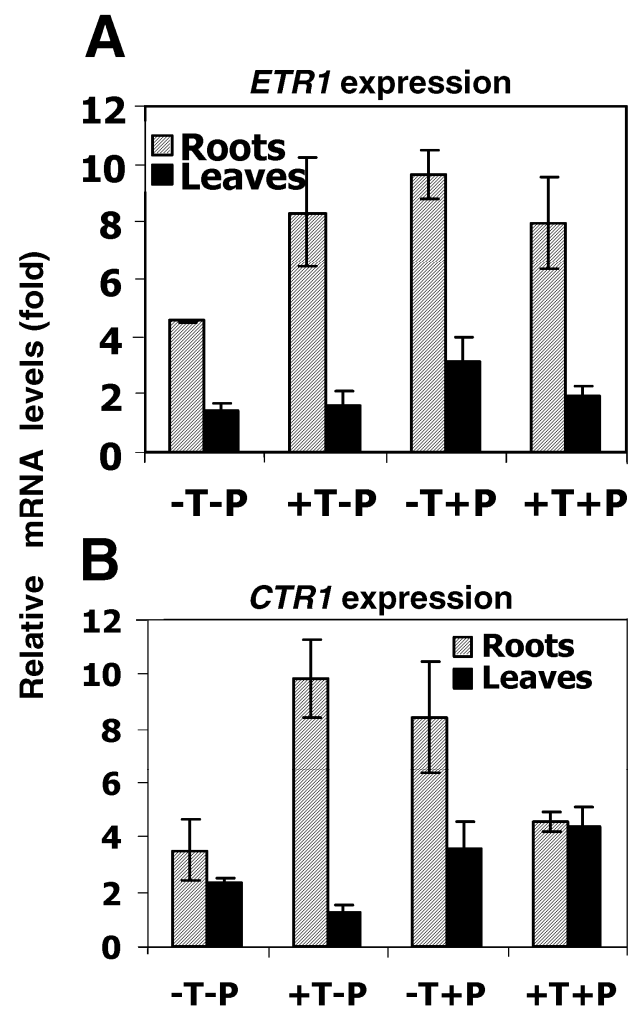

Fig. 8. Relative expression levels of A, ETR1 (ethylene receptor 1 gene) and B, CTR 1 (constitutive triple response 1 gene). Expression was measured in roots (hatched boxes) and leaves (black boxes) of cucumber plants after the following treatments: $-\mathrm{T}-\mathrm{P}$, control; $+\mathrm{T}-\mathrm{P}$, Trichoderma inoculation in the root compartment at time zero; $-\mathrm{T}+\mathrm{P}$, Pseudomonas syringae pv. lachrymans infection of cotyledons at $48 \mathrm{~h}$; and $+\mathrm{T}+\mathrm{P}$, Trichoderma inoculation at time zero and $P$. syringae pv. lachrymans infection at $48 \mathrm{~h}$. Roots and leaves for expression measurements were harvested $48 \mathrm{~h}$ after time of $P$. syringae pv. lachrymans infection.

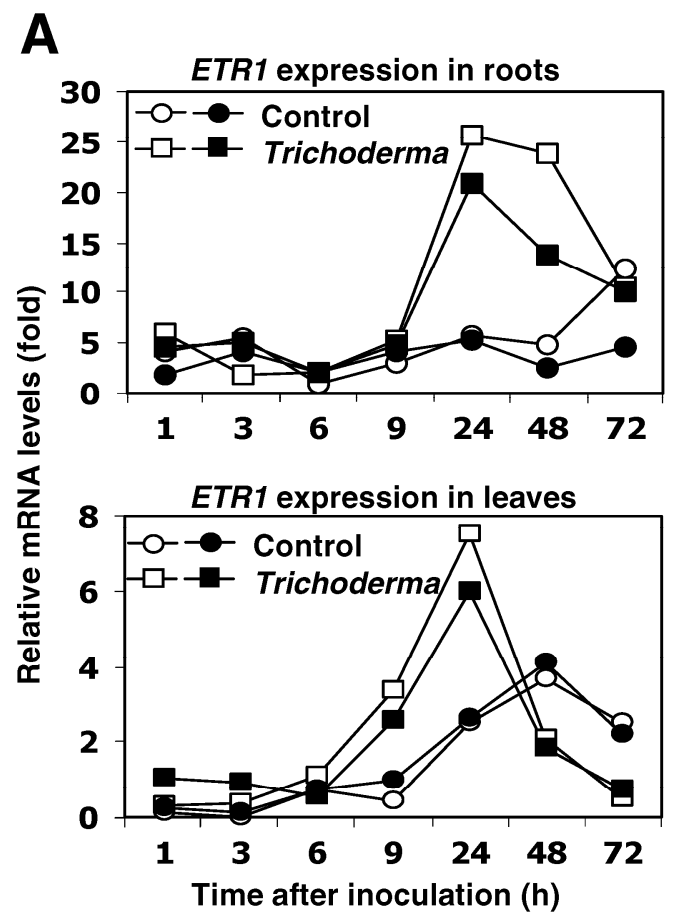

B

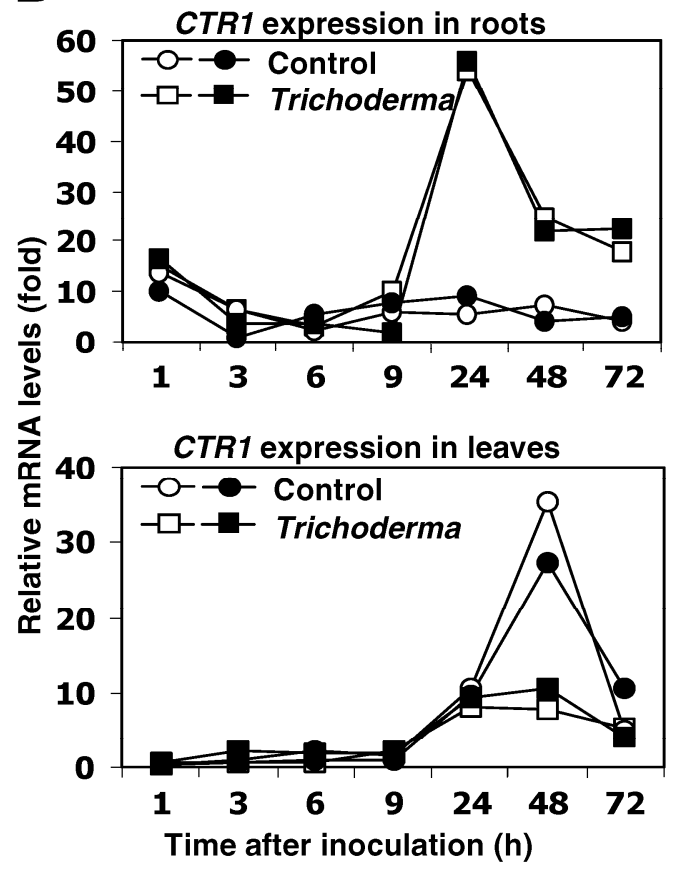

Fig. 7. Time course of the induction of A, ETRI (ethylene receptor 1 gene) and $\mathbf{B}$, CTR1 (constitutive triple response 1 gene) gene expression, respectively. Expression was measured in roots and leaves of cucumber plants after Trichoderma inoculation to the root compartment (time zero). Two experiments were conducted, each including approximately 20 plants. Open symbols signify experiment 1 ; closed symbols signify experiment 2 . The internal standard deviation values for each experiment were smaller than the size of the symbols. $\mathbf{\square}$ and $\square$ indicate inoculation with Trichoderma; $\bullet$ and $\bigcirc$ indicate controls. 
Similarly, the peak of CTRI expression detected in the leaves of noninoculated plants was almost abolished in the Trichodermainoculated plants, indicating down-regulation of the gene (Fig. 7B). This down-regulation of both genes suggests that the negative regulation of the ethylene response was withdrawn in the leaves. This may enhance ethylene sensitivity of the leaves, leading to a higher response in subsequent pathogen challenge. In plants preinoculated with Trichoderma and challenged with $P$. syringae pv. lachrymans, expression of ETRI and CTRI tend to be reduced suggesting that the negative regulation of ETR1/CTR1 on the ethylene defense response was withdrawn in those plants (Fig. 8).

Studies of rhizobacteria-induced ISR demonstrated that there was no change in ethylene production or in expression of ethylene biosynthetic genes in roots or leaves during ethylene-dependent ISR development $(18,26)$. These studies demonstrate that sensitivity to JA and ethylene is required for the rhizobacteria-mediated ISR. Thus, a JA signal induced in Trichoderma-inoculated plants may increase sensitivity to ethylene, perhaps by reducing the negative regulation on the ethylene response pathway.

During plant defense processes, Pal is considered to be activated by the JA/ethylene signaling pathway and was shown to be

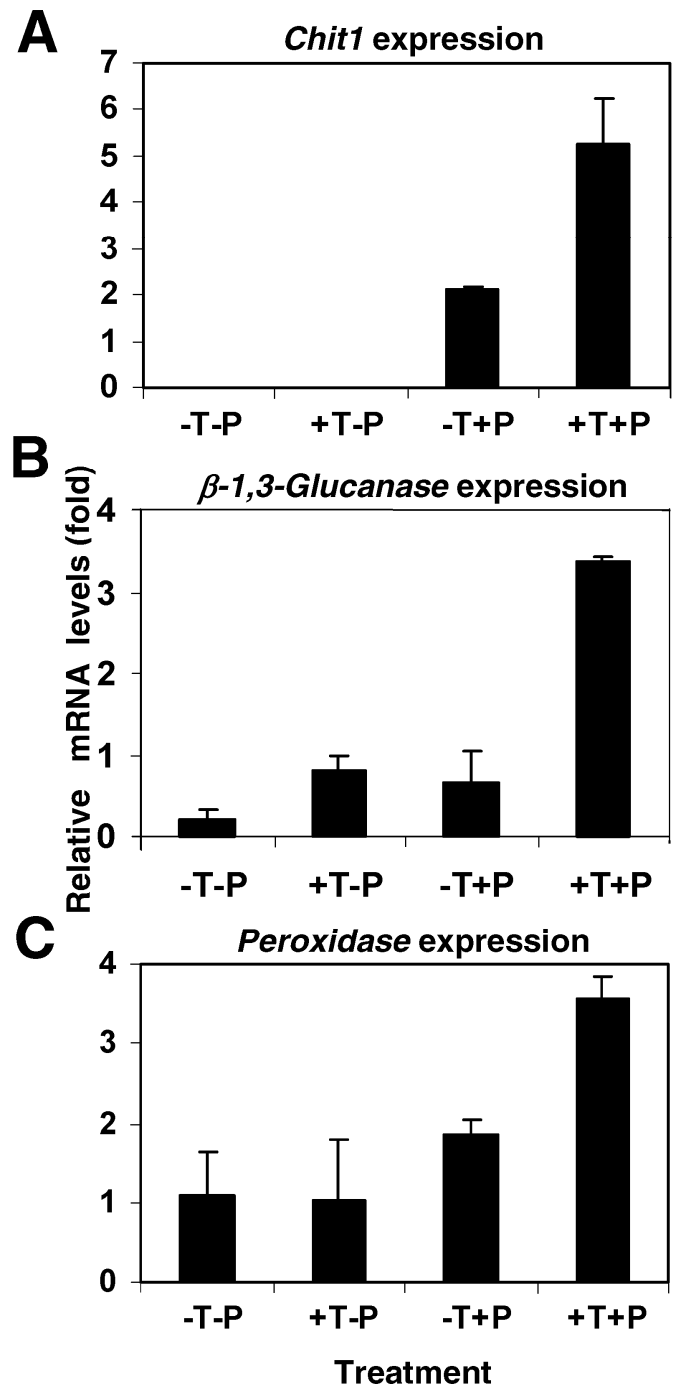

Fig. 9. Relative expression levels of $\mathbf{A}$, Chit1, B, $\beta$-1,3-glucanase gene, and $\mathbf{C}$, peroxidase gene. Expression was measured in leaves of cucumber plants after the following treatments: $-\mathrm{T} \geq \mathrm{P}$, control; $+\mathrm{T}-\mathrm{P}$, Trichoderma inoculation in the root compartment at time zero; $-\mathrm{T}+\mathrm{P}$, Pseudomonas syringae pv. lachrymans infection of cotyledons at $48 \mathrm{~h}$; and $+\mathrm{T}+\mathrm{P}$, Trichoderma inoculation at time zero and $P$. syringae pv. lachrymans infection at $48 \mathrm{~h}$. Leaves were harvested for expression measurements $48 \mathrm{~h}$ post- $P$. syringae $\mathrm{pv}$. lachrymans infection. a key regulatory enzyme in the synthesis of SA $(7,17,23,34)$. We observed two peaks of Pall expression in roots inoculated with Trichoderma, at 1 and 24 hpi (Fig. 3B). Using active Trichoderma cellulase, Martinez et al. (20) also revealed two local peaks of PAL activity after infiltration of melon cotyledons, the first of which appeared before the production of SA. Using a JA signaling inducer (inactive cellulase), they were able to show that the second peak was induced by JA signaling. Correspondingly, our results may suggest that the first peak is independent of SA and the second peak is induced by JA signaling. On the other hand, only the second peak of Pall expression was observed in leaves of Trichoderma-inoculated plants. This suggests that the induction of resistance in systemic tissues by Trichoderma involves only JA signal and not SA signal. In agreement with this, we observed no difference in SA content in leaves of Trichoderma-inoculated and noninoculated plants over a range of several days (Fig. 4).

This idea is supported by additional testing of the expression level of several PR genes. Chitinase 1, a member of the class III chitinases, and $\beta$-1,3-glucanase code for hydrolytic enzymes that disrupt the mycelial cell wall. Chitinase activity is induced in plants by various stimuli, including ethylene and SA $(15,24,30)$. However, $\beta$-1,3-glucanase has been found to be induced mainly by SAR and SAR inducers, such as SA $(16,25,33,37)$. ISRinducing rhizobacteria and MeJA failed to induce the $\beta-1,3-$ glucanase gene in both roots and leaves (37). In Trichodermainoculated plants, temporary activation of the Chit1 gene in roots preceded its temporary activation in leaves (data not shown), suggesting that Chitl activation in leaves relies on the development and transduction of a signal to the leaves. However, $\beta-1,3-$ glucanase was induced only locally (data not shown), indicating that SAR is not involved in Trichoderma-mediated systemic gene expression.

The temporary nature of the increase in defense-related gene expression in response to $T$. asperellum inoculation raised a notable question as to what extent these genes may be activated following challenge infection with a pathogen. A significant elevation in the mRNA levels of Chit1, $\beta$-1,3-glucanase gene, and peroxidase gene was observed in leaves of Trichoderma-induced plants, $48 \mathrm{~h}$ postchallenge with $P$. syringae pv. lachrymans, relative to plants treated exclusively with Trichoderma or $P$. syringae pv. lachrymans (Fig. 9). The same phenomenon was described for the hydroperoxide lyase gene in the same biological system (41). Similar response was described with the Atvsp gene in rhizobacteria-induced ISR in Arabidopsis plants and termed potentiation (37). Our results demonstrate that potentiation of defense-related gene expression may have a wider spectrum, and thus, this mechanism may have a significant contribution to the plant's resistance to pathogens.

Taken together, the results implicate that the main signal transduction pathway through which Trichoderma-mediated ISR is activated uses JA and ethylene as signal molecules, as shown by the involvement of several JA/ethylene pathway-related genes. In addition, the results demonstrate that the Trichoderma-induced state sensitizes the plant to respond more efficiently to subsequent pathogenic attack. This sensitization is apparent from both the reduction in disease symptoms and the systemic potentiation of the PR genes Chit1, $\beta$-1,3-glucanase, and peroxidase. The wide spectrum of this potentiated gene expression suggests its crucial role in ISR mediated by Trichoderma spp.

\section{ACKNOWLEDGMENTS}

This work was supported by grants from "The Dr. Alexander and Myrna Strelinger Endowment Fund" and the United State-Israel Binational Agricultural Research and Developmental Fund (US-3507-04). M. Shoresh is the recipient of a postdoctoral fellowship from the Fienberg Graduate School of Weizmann Institute of Science. We thank S. Mayak and I. Raskin for their help in measuring levels of hormones. 


\section{LITERATURE CITED}

1. Abeles, F. B., Morgan, P. W., and Saltveit, M. E., Jr. 1992. Ethylene in Plant Biology. 2nd ed. Academic Press, San Diego.

2. Avdiushko, S., Croft, K. P., Brown, G. C., Jackson, D. M., HamiltonKemp, T. R., and Hildebrand, D. 1995. Effect of volatile methyl jasmonate on the oxylipin pathway in tobacco, cucumber, and arabidopsis. Plant Physiol. 109:1227-1230.

3. Bate, N. J., and Rothstein, S. J. 1998. C6-volatiles derived from the lipoxygenase pathway induce a subset of defense-related genes. Plant J. 16:561-569.

4. Chang, C., Kwok, S. F., Bleecker, A. B., and Meyerowitz, E. M. 1993. Arabidopsis ethylene-response gene ETR1: Similarity of product to twocomponent regulators. Science 262:539-544.

5. Clark, K. L., Larsen, P. B., Wang, X., and Chang, C. 1998. Association of the Arabidopsis CTR1 Raf-like kinase with the ETR1 and ERS ethylene receptors. Proc. Natl. Acad. Sci. USA 95:5401-5406.

6. Dalisay, R. F., and Kuc, J. A. 1995. Persistence of reduced penetration by Colletotrichum lagenarium into cucumber leaves with induced systemic resistance and its relation to enhanced peroxidase and chitinase activities. Physiol. Mol. Plant Pathol. 47:329-338.

7. Diallinas, G., and Kanellis, A. K. 1994. A phenylalanine ammonia-lyase gene from melon fruit: cDNA cloning, sequence and expression in response to development and wounding. Plant Mol. Biol. 26:473-479.

8. Enyedi, A. J., Yalpani, N., Silverman, P., and Raskin, I. 1992. Localization, conjugation and function of salicylic acid in tobacco during the hypersensitive reaction to tobacco mosaic virus. Proc. Natl. Acad. Sci. USA 89:2480-2484.

9. Harman, G. E., Howell, C. R., Viterbo, A., Chet, I., and Lorito, M. 2004. Trichoderma species-Opportunistic, avirulent plant symbionts. Nature Rev. 44:43-56.

10. Hiraga, S., Sasaki, K., Ito, H., Ohashi, Y., and Matsui, H. 2001. A large family of class III plant peroxidases. Plant Cell Physiol. 42:462-468.

11. Hornung, E., Walther, M., Kuhn, H., and Feussner, I. 1999. Conversion of cucumber linoleate 13-lipoxygenase to a 9-lipoxygenating species by sitedirected mutagenesis. Proc. Natl. Acad. Sci. USA 96:4192-4197.

12. Howell, C. R. 2003. Mechanisms employed by Trichoderma species in the biological control of plant diseases: The history and evolution of current concepts. Plant Dis. 87:4-10.

13. Hua, J., and Meyerowitz, E. M. 1998. Ethylene responses are negatively regulated by a receptor gene family in Arabidopsis thaliana. Cell 94:261271.

14. Huang, Y., Li, H., Hutchison, C. E., Laskeg, J., and Kieber, J. J. 2003. Biochemical and functional analysis of CTR1, a protein kinase that negatively regulates ethylene signaling in Arabidopsis. Plant J. 33:221-233.

15. Ishige, F., Mori, H., Yamazaki, K., and Imaseki, H. 1993. Cloning of a complementary DNA that encodes an acidic chitinase which is induced by ethylene and expression of the corresponding gene. Plant Cell Physiol. 34:103-111.

16. Ji, C., and Kuc, J. 1995. Purification and characterization of an acidic beta-1,3-glucanase from cucumber and its relationship to systemic disease resistance induced by Colletotrichum lagenarium and tobacco necrosis virus. Mol. Plant-Microbe Interact. 8:899-905.

17. Kato, M., Hayakawa, Y., Hyodo, Y., and Yano, M. 2000. Wound-induced ethylene synthesis and expression and formation of 1-aminocyclopropane-1-carboxylate (ACC) synthase, ACC oxidase, phenylalanine ammonia-lyase and peroxidase in wounded mesocarp tissue of Cucurbita maxima. Plant Cell Physiol. 41:440-447.

18. Knoester, M., Pieterse, C. M., Bol, J. F., and Van Loon, L. C. 1999. Systemic resistance in Arabidopsis induced by rhizobacteria requires ethylene-dependent signaling at the site of application. Mol. PlantMicrobe Interact. 12:720-727.

19. Kullnig, C., Krupica, T., Woo, S. L., Mach, R. L., Rey, M., Benitez, T., Lorito, M., and Kubicek, C. P. 2001. Confusion abounds over identities of Trichoderma biocontrol isolates. Mycol. Res.105:770-772.

20. Martinez, C., Blanc, F., Le Claire, E., Besnard, O., Nicole, M., and Baccou, J. C. 2001. Salicylic acid and ethylene pathways are differentially activated in melon cotyledons by active or heat-denatured cellulase from Trichoderma longibrachiatum. Plant Physiol. 127:334-344.

21. Melan, M. A., Dong, X., Endara, M. E., Davis, K. R., Ausubel, F. M., and Patarman, T. K. 1993. An Arabidopsis thaliana lipoxygenase gene can be induced by pathogens, abscisic acid and methyl jasmonate. Plant Physiol. 101:441-450.
22. Menke, F. L. H., Parchmann, S., Mueller, M. J., Kijne, J. W., and Memelink, J. 1999. Involvement of the octadecanoid pathway and protein phosphorylation in fungal elicitor-induced expression of terpenoid indole alkaloid biosynthetic genes in Catharanthus roseus. Plant Physiol. 119:1289-1296.

23. Mitchell, A., and Walters, D. 1995. Systemic protection in barley against powdery mildew infection using methyl jasmonate. Aspects Appl. Biol. 42:323-326

24. Narusaka, Y., Narusaka, M., Horio, T., and Ishii, H. 1999. Comparison of local and systemic induction of acquired disease resistance in cucumber plants treated with benzothiadiazoles or salicylic acid. Plant Cell Physiol. 40:388-395.

25. Newman, M. A., von Roepenack-Lahaye, E., Parr, A., Daniels, M. J., and Dow, J. M. 2002. Prior exposure to lipopolysaccharide potentiates expression of plant defenses in response to bacteria. Plant J. 29:487495.

26. Pieterse, C. M. J., Van Pelt, J. A., Ton, J., Parchmann, S., Mueller, M. J., Buchala, A. J., Métraux, J.-P., and van Loon, L. C. 2000. Rhizobacteria-mediated induced systemic resistance (ISR) in Arabidopsis requires sensitivity to jasmonate and ethylene but is not accompanied by an increase in their production. Physiol. Mol. Plant Pathol. 57:123134.

27. Pieterse, C. M. J., Van Pelt, J. A., Verhagen, B. W. M., Ton, J., van Wees, S. C. M., Léon-Kloosterziel, K. M., and van Loon, L. C. 2003. Induced systemic resistance by plant growth promoting rhizobacteria. Symbiosis 35:39-54.

28. Reymond, P., and Farmer, E. E. 1998. Jasmonate and salicylate as global signals for defense gene expression. Curr. Opin. Plant Biol. 1:404-411.

29. Rodriguez, F. I., Esch, J. J., Hall, A. E., Binder, B. M., Schaller, G. E., and Bleecker, A. B. 1999. A copper cofactor for the ethylene receptor ETR1 from Arabidopsis. Science 283:996-998.

30. Salzer, P., Bonanomi, A., Beyer, K., Vogeli-Lange, R., Aeschbacher, R. A., Lange, J., Wiemken, A., Kim, D., Cook, D. R., and Boller, T. 2000. Differential expression of eight chitinase genes in Medicago truncatula roots during mycorrhiza formation, nodulation, and pathogen infection. Mol. Plant-Microbe Interact. 13:763-777.

31. Samac, D. A., and Shah, D. M. 1991. Developmental and pathogen induced activation of the Arabidopsis acidic chitinase promoter. Plant Cell 3:1063-1072.

32. Samuels, G. J. 1996. Trichoderma: A review of biology and systematics of the genus. Mycol. Res. 100:923-935.

33. Shan, J., and Klessig, D. F. 1996. Identification of a salicylic acidresponsive element in the promoter of the tobacco pathogenesis-related beta-1,3-glucanase gene, PR-2d. Plant J. 10:1089-1101.

34. Sticher, L., Mauch-Mani, B., and Métraux, J. P. 1997. Systemic acquired resistance. Annu. Rev. Phytopathol. 35:235-270.

35. Thompson, J. E., Mayak, S., Shinitzky, M., and Halevy, A. H. 1982. Acceleration of membrane senescence in cut carnation flowers by treatment with ethylene. Plant Physiol. 69:859-863.

36. van Loon, L. C., Bakker, P. A. H. M., and Pieterse, C. M. J. 1998. Systemic resistance induced by rhizosphere bacteria. Annu. Rev. Phytopathol. $36: 453-483$.

37. van Wees, S. C. M., Luijendijk, M., Smoorenburg, I., van Loon, L. C., and Pieterse, C. M. J. 1999. Rhizobacteria-mediated induced systemic resistance (ISR) in Arabidopsis is not associated with a direct effect on expression of known defense-related genes but stimulates the expression of the jasmonate-inducible gene Atvsp upon challenge. Plant Mol. Biol. 41:537-549.

38. Yedidia, I., Benhamou, N., and Chet, I. 1999. Induction of defense responses in cucumber plants (Cucumis sativus L.) by the biocontrol agent Trichoderma harzianum. Appl. Environ. Microbiol. 65:1061-1070.

39. Yedidia, I., Benhamou, N., Kapulnik, Y., and Chet, I. 2000. Induction and accumulation of PR proteins activity during early stages of root colonization by the mycoparasite Trichoderma harzianum strain T-203. Plant Physiol. Biochem. 38:863-873.

40. Yedidia, I., Shoresh, M., Kerem, Z., Benhamou, N., Kapulnik, Y., and Chet, I. 2003. Concomitant induction of systemic resistance to Pseudomonas syringae pv. lachrymans in cucumber by Trichoderma asperellum (T-203) and accumulation of phytoalexins. Appl. Environ. Microbiol. 69:7343-7353.

41. Yedidia, I., Srivasta, A. K., Kapulnik, Y., and Chet, I. 2001. Effect of Trichoderma harzianum on microelement concentrations and increase growth of cucumber plants. Plant Soil 235:235-242. 